\title{
KEPERCAYAAN DALAM SIKLUS KEHIDUPAN PADA MASYARAKAT SUNDA PESISIR (KECAMATAN PAMEUNGPEUK, KABUPATEN GARUT, JAWA BARAT)
}

\author{
Risma Rismelati, Asri Soraya Afsari, Ayu Septiani, \\ Fakultas Ilmu Budaya, Universitas Padjadjaran
}

\begin{abstract}
Abstrak
Setiap bangsa di berbagai belahan dunia ini pastinya memiliki tradisi leluhur yang bertahan dan berkembang dari generasi ke generasi. Tradisi tersebut kemudian menjadi sebuah identitas diri yang mencerminkan nilai-nilai budaya yang unik dan berkarakter. Menurut Clyde dan Kluckhohn dalam Pelly (1994), nilai budaya merupakan sebuah konsep beruang lingkup luas yang hidup dalam alam pikiran sebagian besar warga suatu masyarakat, mengenai apa yang paling berharga dalam hidup. Nilai budaya itu akhirnya tumbuh menjadi suatu kepercayaan masyarakat yang dijadikan sebagai aturan paling mendasar dalam menjalani siklus kehidupan. Hal ini dapat dilihat secara nyata dalam siklus kehidupan masyarakat Sunda di wilayah pesisir Jawa Barat. Fokus kepercayaan di sini adalah bentuk-bentuk tradisi yang masih dilakukan secara turun temurun dalam fase kehidupan manusia, seperti fase kelahiran, pernikahan dan kematian. Maka dari itu penelitian ini akan fokus mengkaji kepercayaan yang berkaitan dengan siklus kehidupan pada masyarakat Pameungpeuk, Kabupaten Garut, Jawa Barat. Untuk mencapai tujuan tersebut digunakan metode kualitatif deskriptif. Dalam mengumpulkan data digunakan metode lapangan karena peneliti terjun langsung ke masyarakat, melakukan wawancara langsung pada nara sumber dan melakukan metode survey melalui penyebaran data kuesioner.
\end{abstract}

Kata Kunci: Kelahiran, Kematian, Kepercayaan, Pameungpeuk, Pernikahan, Siklus Kehidupan

\section{PENDAHULUAN}

Indonesia adalah bangsa yang memiliki keberagaman suku dan budaya. Setiap suku memiliki keberagaman adat atau kebiasaan dalam menjalankan kehidupan sehari-hari maupun upacara adat yang berupa seremonial yang menggunakan berbagai ritual yang berbeda-beda di setiap pelaksanaannya. Tidak jarang pula adat ini turut mengatur segala aspek kehidupan masyarakatnya terutama hal-hal yang krusial, misalkan seperti melahirkan, khitanan, menikah dan meninggal. Proses perjalanan hidup manusia tersebut dikenal dengan istilah siklus atau daur kehidupan manusia. Antara fase yang satu dengan fase berikutnya saling berkesinambungan. Karena untuk mencapai suatu fase kehidupan, manusia harus melewati lebih dulu fase sebelumnya. Dalam tiap-tiap fase kehidupan tersebut, manusia dihadapkan pada lingkungan yang membesarkan mereka. Oleh karenanya terdapat interaksi sosial dalam pembentukan karakter seorang manusia. Dalam interaksi sosial tersebut biasanya dilakukan penanaman nilai-nilai seperti nilai agama, nilai sosial, dan nilai budaya yang berlaku bagi masyarakat tersebut. Penanaman nilai-nilai tersebut dapat dilakukan dengan berbagai cara, satu di antaranya melalui pembelajaran dari suatu kepercayaan yang dianggap dapat menjadi aturan atau rambu-rambu dalam bersikap dan bertingkah laku di kehidupan sehari-hari.

Berkaitan dengan artikel ini, penulis mengkaji kepercayaan dalam siklus kehidupan suatu masyarakat yang menjadi aturan dalam menjalani kehidupan sehari-hari. Masyarakat yang dimaksud dalam penelitian ini adalah masyarakat Sunda di wilayah Pameungpeuk, Kabupaten Garut, Jawa Barat. Pemilihan wilayah tersebut didasarkan pada dugaan kuat peneliti bahwa masyarakat di wilayah itu masih memiliki kepercayaan terhadap hal-hal yang boleh dan tidak boleh, harus dan tidak harus dilakukan dalam tiap-tiap fase kehidupan manusia. Oleh karena itu penelitian ini bertujuan untuk mengkaji bentuk-bentuk kepercayaan dalam siklus kehidupan masyarakat Sunda di wilayah Pameungpeuk, Kabupaten Garut, Jawa Barat.

\section{KAJIAN TEORI}

Menurut Clyde dan Kluckhohn dalam Pelly (1994), nilai budaya merupakan sebuah konsep beruang lingkup luas yang hidup dalam alam pikiran sebagian besar warga suatu masyarakat, mengenai apa yang paling berharga dalam hidup. 
Nilai budaya itu akhirnya tumbuh menjadi suatu kepercayaan masyarakat yang dijadikan sebagai aturan paling mendasar dalam menjalani siklus kehidupan. Hal ini dapat dilihat secara nyata dalam siklus kehidupan masyarakat Sunda di wilayah pesisir Jawa Barat. Fokus kepercayaan di sini adalah bentuk-bentuk tradisi yang masih dilakukan secara turun temurun dalam fase kehidupan manusia, seperti fase kelahiran, pernikahan dan kematian.

Penelitian ini menggunakan metode kualitatif deskriptif dengan mengambil dua sumber data, yaitu sumber data primer dan sumber data sekunder. Sumber data primer adalah data di lapangan mealui participant observation. Selanjutnya, untuk melengkapi data primer, digunakan pula data sekunder, yaitu sumber kepustakaan. Dalam penelitian ini, untuk memperoleh sumber data primer digunakan teknik partisipant observation (Adler dan Adler, 1994: 377), indepth interview (Fontana dan Frey, 1994: $365 \square 366$ ), GDQ VWXGL NHSXVWDNDDQ. Partisipant observation dipilih untuk menjalin hubungan baik dengan informan. Pengamatan dilakukan ke lapangan atau ke lokasi penelitian untuk memperoleh deskripsi mengenai kepercayaan dalam siklus kehidupan masyarakat Sunda di Kecamatan Pameungpeuk, Kabupaten Garut Jawa Barat.

Pameungpeuk merupakan salah satu kecamatan di Kabupaten Garut, Provinsi Jawa Barat yang berjarak sekitar $86 \mathrm{~km}$ dari pusat Kota Garut ke selatan. Pusat pemerintahannya berada di Desa Mandalakasih. Kecamatan ini terletak di wilayah Garut Selatan dan menjadi pusat kecamatan paling berkembang di kawasan ini. Kecamatan Pameungpeuk sebelumnya disebut Nagara karena diduga akan ramai seperti Pelabuhan SundaKelapa di Jakarta (dahulu Batav ia). Awalnya kecamatan ini merupakan bagian dari Kabupaten Soekapoera sebelum menjadi bagian dari Kabupaten Garut. Sedari zaman Belanda, Pameungpeuk dikenal sebagai salah satu destinasi wisata pesisir laut selatan karena keindahan alamnya. Sehingga, sejak zaman penjajahan Belanda pulalah, infrastruktur jalan dari Kota Garut menuju Pameungpeuk sudah terbangun. Penjajah memiliki kepentingan membangun jalan untuk mempermudah akses pengangkutan hasil perkebunan teh dan karet. Dulunya, perkebunan teh membentang dari Cikajang hingga Neglasari. Kini, tanaman teh hanya dijumpai sepenggalsepenggal. Perkebunan karet di kawasan seperti
Cilaut, Nagara, dan Cimari juga tak lagi berproduksi. Selain kejutan kelokan tajam, pemandangan pepohonan hutan, dan perkebunan teh, jalanan menuju Pameungpeuk juga menghadirkan kecantikan air terjun alami. Keindahan air terjun dengan sungai-sungai berair jernih ini semakin menjadi limpahan pemandangan jika wisatawan menempuh jalan dari arah Ciwidey atau Pengalengan menyusuri pantai selatan menuju Pameungpeuk. Selain itu, obyek wisata yang digadang-gadang untuk promosi tak lain adalah Pantai Cilauteureun. Teluk Cilauteureun menjadi zona wisata yang luar biasa yang menghadap langsung ke Samudra Indonesia (melalui https: // naratasgaroet. net/2016/06/24/ sadjarahpameungpeuk-poesaka-soenda-1924/ dan https://travel.kompas.com/ $\mathrm{read} / 2015 / 03 / 25 / 122700327 /$ Kenangan.Sepenggal. Pameungpeuk diakses pada 3 September 2018)

Secara administratif, kecamatan Pameungpeuk terdiri atas 8 desa, yakni Desa Bojong, Bojong Kidul, Jatimulya, Mancagahar, Madalakasih, Paas, Pameungpeuk dan Sirnabakti (Laporan Bulanan Kecamatan Pameungpeuk, Kabupaten Garut, Juni 2018).

\section{PEMBAHASAN}

Siklus kehidupan manusia merupakan putaran hidup yang dialami manusia secara berulang-ulang secara tetap dan teratur. Berkait dengan artikel ini, putaran hidup yang dibahas meliputi kelahiran, pernikahan, dan kematian. Sebelum seorang ibu melahirkan, dia menjalani proses kehamilan terlebih dulu. Berdasarkan penuturan dari narasumber, adat kebiasaan dalam menjaga orang yang hamil, dengan maksud melindunginya dari pengaruh buruk atau jahat para Lelembut (makhluk halus) atau Dedemit (siluman) dan dari pengaruh buruk kekuatan alam sekitar yang juga bersifat gaib. Upaya perlindungan itu dilakukan dengan berbagai cara seperti mengadakan selamatan; membekali orang hamil dengan benda-benda yang diyakini memiliki kekuatan penolak bala atau sebagai jimat guna menangkal atau melenyapkan pengaruh jahat yang merusak, yang ditimbulkan oleh makhluk halus atau kekuatan alam yang tidak terlihat itu; mengawasi dan menjaga agar yang hamil tidak melanggar pantrangan (pantangan) dari karuhun (leluhur). Untuk yang pertama kali hamil, orang tuanyalah yang akan menanganinya. Tapi bagi yang telah dua atau tiga kali hamil, dapat melakukannya sendiri. Masa awal kehamilan 
sampai tiga bulan dikatakan ngandeg atau nyiram. Setelah genap tiga bulan, baru dikatakan hamil, saat itulah diadakan selamatan pertama (salametan tilu bulanna). Hidangan yang disajikan berupa bubur beureum dan bubur bodas, kue-kue tradisional dan nasi kuning, sebagai suguhan untuk para pembaca doa dan antaran untuk para tetangga dekat. Setelah selamatan hamil tiga bulan, diadakan lagi selamatan pada masa kehamilan genap lima, tujuh dan sembilan bulan. Intinya harus mengikuti bilangan ganjil.

Dalam selamatan yang kedua kalinya, diadakan hajat bangsal. Gabah padi (Bengsal) diwadahi dengan bokor dan di atasnya ditutup dengan waluh $(l a b u)$. Hal ini mengandung kias, yakni kata Bengsal secara metronomis bertautan dengan kata waluya (selamat). Kata bengsal dalam ucapan orang Sunda sering muncul dalam bentuk kata majemuk balabengsal yang berarti segala kesialan. Jadi, maksud dari hajat bengsal sudah bisa ditebak, yaitu menghilangkan segala kesialan dan diganti dengan kawaluyaan (keselamatan). Selamatan yang ketiga kalinya diadakan pada saat kehamilan genap tujuh bulan yang juga merupakan selamatan yang terbesar di antara keempat selamatan. Selamatan ini disebut tingkeban atau babarik atau babarit. Sejak tingkeban segala urusan pengawasan dan penjagaan berada di tangan paraji, tidak lagi di tangan orang tua. Dalam selamatan keempat kalinya, ketika hamil sembilan bulan, diadakan sedekah lolos (penganan dari tepung beras bergula yang dilumuri dengan minyak dari santan, dibungkus dengan daun pisang, sehingga mudah lepas) adalah kias agar pada saat bersalin, bayi keluar dengan lancar dan selamat, sedangkan lampu merupakan kias agar bayinya menjadi anak yang terang hatinya. Selanjutnya, Paraji meminta agar keluarga yang hamil mengadakan persediaan berbagai ramuan yang diperlukan untuk digunakan pada saat sebelum dan sesudah bersalin. Ramuan itu berupa biji-bijian, akar-akaran, daun-daunan, dan umbi-umbian tertentu yang di pedesaan tidak terlalu sulit diperoleh karena bisa dipetik di alam sekitar. Karena itulah masa kehamilan sembilan bulan biasa pula disebut bulan alaeun yang berarti bulan saat memetik.

Siklus yang kedua yaitu pernikahan. Adat pernikahan yang masih dilaksanakan oleh masyarakat adalah adat siraman. Narasumber menuturkan bahwa untuk siraman pengantin menggunakan kembang tujuh rupa dan uang koin, biasanya dilaksanakan sehari sebelum pernikahan dilangsungkan. Fungsinya untuk membersihkan diri pengantin dan dijauhkan dari hal-hal buruk. Selanjutnya ada daun sirih yang digunakan pada saat sawéran, ditambah dengan uang seribu, fungsinya supaya langgeng berumah tangga. Kemudian prosesi tarik menarik ayam bakakak antara pasangan suami dan istri. Siapa yang mendapatkan potongan ayam paling besar, berarti rezekinya lebih besar.

Siklus kehidupan yang ketika adalah kematian. Dalam hal kematian, masyarakat sudah dipengaruhi oleh Agama Islam, jadi ada sebagian kebiasaan yang telah bergeser namun ada juga yang masih dipertahankan. Berdasarkan hasil wawancara dengan narasumber, dalam hal yang dipertahankan adalah kemenyan sebagai wewangian ketika jenazah disemayamkan di rumah duka. Selain itu, tanaman hanjuang yang harus ditanam di lokasi pemakaman. Bagi masyarakat Sunda tanaman hanjuang tidak saja untuk estetika, melainkan juga dikeramatkan. Mereka mengartikan tanaman hanjuang sebagai pembatas ruang. Berkait dengan kematian seseorang, tanaman hanjuang digunakan sebagai pembatas makam yang satu dengan makam yang lainnya (Sunarni, International Seminar Prasasti III; Current Research in Linguistics, tanpa tahun).

\section{SIMPULAN}

Berdasarkan pemaparan di atas dapat ditarik simpulan bahwa masyarakat Sunda pada umumnya dan masyarakat Sunda di pesisir yaitu di Kecamatan Pameungpeuk, Kabupaten Garut khususnya, masih menjalankan tradisi dalam siklus kehidupan mereka. Tradisi tersebut dijalankan sebagai bentuk penghormatan terhadap leluhur yang mewarisi tradisi. Meskipun demikian, seiring dengan perkembangan zaman dan masuknya Agama Islam ke Indonesia, ada beberapa tradisi yang hilang karena dianggap tidak relevan lagi dengan perkembangan zaman atau dengan ajaran baru tersebut. Namun, hilangnya tradisi tidak secara serta merta melainkan melalui proses yang panjang yang terjadi dalam lingkup masyarakat pendukungnya.

\section{DAFTAR PUSTAKA}

\section{Buku}

Adler, Peter dan Patricia A. Adler. 1994. "Observational Techniques" dalam Norman 
K. Denzin dan Yvonna S. Lincoln (ed.) Handbook of Qualitative Research. London-New Delhi: Sage Publications.

Ekadjati, Edi. S. 2009. Kebudayaan Sunda: Suatu Pendekatan Sejarah (Cetakan Ketiga). Jakarta: Pustaka Jaya.

Fontana, Andrea dan James H. Frey. 1994. "Interviewing The Art of Science" dalam Norman K. Denzin dan Yvonna S. Lincoln (ed.) Handbook of Qualitative Research. London-New Delhi: Sage Publications.

Laporan Bulanan Kecamatan Pameungpeuk, Kabupaten Garut, Juni 2018.

Soelaeman, Moenandar. 2007. Ilmu Budaya Dasar: Suatu Pengantar (Cetakan Keempat). Bandung: Refika Aditama.

Spradley, James P. 1997. Metode Etnografi. Yogyakarta: Tiara Wacana.

Sunarni, Nani. "The Socio-Cultural Values of The Lexeme 'Hanjuang' in The Sundanese Language: A Study in Ethnolinguistics". Makalah pada International Seminar Prasasti III: Current Research in Linguistics. Tanpa tahun.
Yus, Rusyana dkk. 1989. Pandangan Hidup Orang Sunda: Seperti tercermin dalam Kehidupan Masyarakat Dewasa ini (Tahap III). Bandung: Proyek Penelitian dan Pengkajian Kebudayaan Nusantara, 1988.

\section{Website}

"Kenangan Sepenggal Pameungpeuk", melalui https://ravel.kompas.com/read/2015/03/25/122700 327/Kenangan.Sepenggal.Pameungpeuk diakses pada 3 September 2018.

Putri, Amanda. 2015. Ritus-ritus atau Tata Cara Kelahiran-Pendewasaan melalui www. shiritoriofficial. wordpress. com /2015/03/11/ japan-fact-8/amp/, diakses pada 15 Januari 2018.

"Sadjarah Pameungpeuk", melalui https://naratasgaroet.net/2016/06/24/ sadjarahpameungpeuk-poesaka-soenda-1924/ diakses pada 3 September 2018.

Sumber Lisan

Nama : Drs.Yusuf Firdaus

Jabatan : Sekretaris

Kecamatan Pameungpek, Kabupaten Garut 